\title{
Histone Acetyltransferase KAT6A
}

National Cancer Institute

\section{Source}

National Cancer Institute. Histone Acetyltransferase KAT6A. NCI Thesaurus. Code C71449.

Histone acetyltransferase KAT6A (2004 aa, $225 \mathrm{kDa}$ ) is encoded by the human KAT6A gene. This protein is a histone acetyltransferase that is involved in the regulation of transcription. 